\title{
PENGARUH KUALITAS PELAYANAN DAN KUALITAS PRODUK TERHADAP KEPUASAN KONSUMEN PADA RESTORAN KFC LAMPUNG
}

\author{
Mutiara Zahara ${ }^{1}$, Nando Andreansyah ${ }^{2}$, Relawati $^{3}$, Vicky F Sanjaya $^{4}$ \\ Program Studi Manajemen Bisnis Syariah, Univeristas Islam Negeri Raden Intan Lampung \\ mutiarazahara19@gmail.com, nandoandreansyah33@gmail.com, rhela2904@gmail.com, \\ vicky@ radenintan.ac.id
}

\begin{abstract}
Abstrak. Penelitian ini bertujuan untuk mengetahui pengaruh kualitas pelayanan dan kualitas produk terhadap kepuasaan konsumen pada Restoran KFC Lampung. Jenis penelitian kuantitatif dengan sampel berjumlah 92 responden melalui metode purposive sampling. Teknik pengumpulan data menggunakan kuesioner. Uji validitas dan reliabilitas serta uji statistic dilakukan dengan menggunakan metode berbasis aplikasi PLS. Perolehan hasil penelitian yang didapat menunjukkan bahwa kualitas pelayanan dan kualitas produk berpengaruh signifikan terhadap kepuasaan konsumen pada Restoran KFC Lampung.
\end{abstract}

Kata Kunci : Kualitas Pelayanan, Kualitas Produk, dan Kepuasan Konsumen.

\section{THE EFFECT OF QUALITY SERVICE AND PRODUK QUALITY TO CONSUMER SATISFACTION AT KFC LAMPUNG}

\author{
Mutiara Zahara ${ }^{1}$, Nando Andreansyah ${ }^{2}$, Relawati $^{3}$, Vicky F Sanjaya ${ }^{4}$ \\ Program Studi Manajemen Bisnis Syariah, Univeristas Islam Negeri Raden Intan Lampung \\ mutiarazahara19@gmail.com, nandoandreansyah33@gmail.com, rhela2904@gmail.com, \\ vicky@ radenintan.ac.id
}

\begin{abstract}
This study aims to determine the effect of service quality and product quality on consumer satisfaction at KFC Lampung Restaurant. This type of quantitative research with a sample of 92 respondents through purposive sampling method. The data collection technique used a questionnaire. Validity and reliability tests and statistical tests were carried out using the PLS application-based method. The research results obtained indicate that service quality and product quality have a significant effect on consumer satisfaction at KFC Lampung Restaurant.
\end{abstract}

Keywords : Service Quality, Product Quality, and Customer Satisfaction. 


\section{PENDAHULUAN}

Seiring dengan perkembangan zaman dan dengan meningkatnya taraf kehidupan masyarakat memberikan pengaruh terhadap pola konsumsi dan prilaku masyarakat dalam memenuhi kebutuhannya. Salah satu gaya hidup yang berkembang saat ini adalah mengkonsumsi makanan yang ditawarkan oleh restoran cepat saji. Makanan cepat saji menjadi pilihan utama bagi masyarakat perkotaan terutama bagi masyarakat yang memiliki rutinitas dan kesibukan setiap harinya. Hal tersebut berdampak pada timbulnya kebutuhan masyarakat terhadap makanan yang cepat dan instant. Hal ini bisa kita lihat dengan ramainya pengunjung restoran cepat saji setiap harinya. Kehadiran fast food sangat disukai oleh masyarakat perkotaan karena cara penyajiannya yang cepat sehingga memudahkan untuk menyantapnya dimana saja. Seperti kata Chen-Bo Zhong, peneliti dari University of Toronto, "Fast food telah mewakili budaya saat ini yang membutuhkan waktu cepat dan kepuasan instant".

Makanan cepat saji atau Fast Food merupakan hidangan alternatif yang biasanya berupa ayam goreng, kentang goreng, burger, pasta, atau roti isi. Restoran cepat saji merupakan salah satu perusahaan yang bergerak dibidang penyediaan makanan, minuman dan penyediaan layanan lainnya. Salah satu restoran cepat saji yang banyak diminati oleh masyarakat perkotaan adalah Kentucky Fried Chicken (KFC)). Kentucky Fried Chicken (KFC) adalah salah satu perusahaan cepat saji yang menyediakan ayam goreng cepat saji terbaik saat ini.

Meskipun banyak kuliner fast food lainnya seperti McDonals, Texas Fried Chicken, Hoka Hoka Bento yang juga menawarkan produk serupa dengan KFC, namun KFC mampu meraih posisi pertama dalam ajang penghargaan Top Brand Award selama tiga tahun terakhir menjadi Top Brand untuk kategori fast food (makan cepat saji).

Menurut (Siu \& Tak-Hing Cheung, 2011) menyatakan bahwa pengukuran kualitas pelayanan masih sulit dilakukan pada sektor jasa karena karakteristik unit dari jasa yaitu : Intangibility, Heterogenity, inserapabelity dan Perihability. Dan menyarankan untuk peneliti selanjutnya Saran dari peneliti selanjutnya dapat diteliti mengenai faktor - faktor lain seperti faktor harga atau kualitas produk. Menurut kolter (2000) beranggapan bahwa terdapat hubungan yang erat antara produksi dan pelayanan Saran untuk peneliti selanjutnya untuk mengembangkan penelitian ini dengan mempertimbangkan variabel-variable lain yang merupakan variabel lain diluar variabel yang sudah masuk dalam penelitian ini, misalnya : Harga, Kualitas Produk, dan Dining atmosphere.

Menurut Hartanto \& Andreani (2019) yang menyatakan bahwa kualitas produk tidak memiliki pengaaruh yang signifikan terhadap kepuasan pelanggan. dari jurnal Dika Lambang Krisdianti, Sunarti (2019), Dengan Judul "Pengaruh Kualitas Pelayanan Terhadap Kepuasan Konsumen Pada Restoran Pizza Hut Malang Town Square" disini kami mengganti studi kasusnya menjadi Restoran KFC LAMPUNG. Berdasarkan Gap tersebut 
maka penulis ingin melakukan pengujian dengan menambahkan variabel kualitas produk untuk dianalisis apakah kualitas produk mempengaruhi kepuasan konsumen terhadap produksi KFC Lampung.

\section{TINJAUAN PUSTAKA DAN PENGEMBANGAN HIPOTESIS}

Pengaruh Kualitas Pelayanan Terhadap Kepuasan Konsumen

Menurut Familiar dan Ida maftukhah (2015) menyatakan bahwa kualitas pelayanan yang ideal adalah ketika pelayanan yang diterima melampaui harapan konsumen dan sebaliknya apabila pelayanan yang diterima lebih rendah dari yang diharapkan maka kualitas pelayanan dianggap buruk. Fandy Tjiptono (2012) juga Menyatakan kualitas pelayanan adalah tingkat keunggulan yang yang diharapkan dan pengenndalian atas tingkat keunggulan untuk memenuhi keinginan konsumen. Rahmadani, Suardana, dan samudra. Kualitas pelayanan mempunyai efek secara langsung terhadap kepuasan konsumen. Penelitian Sebelumnya Menurut Dika Krisdianti (2019) Kualitas pelayanan mempunyai pengaruh yang signifikan secara serentak terhadap kepuasan konsumen. Menurut Muhammad Ryan Fauzi dan Kastawan Mandala (2019). Menurut Joko Bagio Santoso (2019) Kualitas layanan berpengaruh positif dan signifikan terhadap kepuasan pelanggan. Kualitas pelayanan memiliki pengaruh terhadap kepuasan konsumen.

$\mathrm{H}_{1}$ : Kualitas pelayanan berpengaruh positif signifikan terhadap kepuasan konsumen.

Pengaruh Kualitas Produk Terhadap Kepuasan Konsumen

Menurut Assauri (2015) Kualitas produk adalah pernyataan tingkat kemampuan dari suatu merk atau produk tertentu dalam melaksanakan fungsi yang diharapkan dan sebagai bahan untuk memenuhi kebutuhan dasar manusia. Sedangkan menurtut Weenas (2013), Kualitas produk merupakan salah satu hal yang dapat mempengaruhi kepuasan konsumen. Penelitian sebelumya Menurut Purnomo Edwin Setyo (2017) Kualitas produk berpengaruh secara signifikan terhadap kepuasan konsumen. Hal ini sesuai dengan penelitian terdahulu yang sudah dilakukan. Menurut Muhammad Ryan Fauzi dan kastawan mandala (2019) Kualitas produk berpengaruh positif dan signifikan terhadap kepuasan pelanggan. Menurut Malik Ibrahim Siti Marijam Thawil (2019). Kualitas produk telah membuktikan hubungan dan signifikan variasi dari kepuasan konsumen. Sedangkan menurut Hartanto dan Andreani (2019). Kualitas produk tidak memiliki pengaruh yang signifikan terhadap kepuasan konsumen.

$\mathrm{H}_{2}$ : Kualitas produk berpengaruh positif signifikan terhadap kepuasan konsumen.

\section{KUALITAS PELAYANAN}

Tjipto dan Chandra (2011) mendefinisikan kualitas pelayanan sebagai bentuk upaya dalam mewujudkan kebutuhan, keinginan pembeli, serta ketepatan penyampaian produk tersebut agar dapat mengimbangi harapan pembeli.

Terdapat 5 Indikator untuk kualitas pelayanan, yaitu:

1) Bukti fisik (tangible), merupakan bukti langsung yang dapat secara langsung dinilai melalui visual atau tampilan dari fasilitas fisik. Seperti : keamanan parkir saat berbelanja, penampilan karyawan menarik, desain gedung yang unik dan menarik.

2) Keandalan (reliability), merupakan dimensi kesamaan atau sesuai tidaknya pelayanan yang diberikan terhadap apa yang dijanjikan kepada 
pelanggan baik dengan pemberian informasi yang sesuai hingga bentuk pelayanan yang handal dan tepat waktu (onetime). Seperti : ketelitian kasir melayani pelanggan, daya tanggap/respon karyawan membantu pelanggan berbelanja dan dan kemampuan karyawan menguasai penempatan produk.

3) Daya tanggap (responsiveness), merupakan bentuk kesediaan karyawan dalammemberikan pelayanan kepada konsumen. Seperti : kecepatan karyawan menangani masalah pelanggan, kemauan karyawan memberikan perhatian secara individu, dan ketanggapan informasi yang jelas kepada pelanggan.

4) Jaminan (assurance), merupakan dimensi yang dapat memberikan jaminan atau rasa aman kepada konsumen sehingga akan menumbuhkan rasa percaya terhadap perusahaan. Seperti : kemudahan berkomunikasi antar karyawan dengan para pelanggan dan pemberian informasi yang jelas kepada pelanggan

5) Empati (emphaty), merupakan dimensi kesediaan perusahaan untuk memperhatikan kebutuhan konsumen dan kesediaan dalam memberi kemudan atau bantuan ketika konsumen mengalami permasalahan baik sebelum maupun setelah mengkonsumsi produk yang ditawarkan perusahaan. Seperti : kemampuan berkomunikasi dengan pelanggan dan kemudahan dalam mendapat informasi produk.

\section{KUALITAS PRODUK}

Kotler dan Keller (2009) menjelaskan bahwa kualitas produk adalah suatu kondisi dinamis dari produk atau barang yang mempunyai manfaat bagi konsumen sesuai dengan kebutuhan dan harapan komsumen.

Terdapat 3 indikator yang mempengaruhi kualitas produk, yaitu:

1) Spesifikasi Produk, adalah kriteria dari barang/jasa yang dapat memenuhi kebutuhan pengguna barang/jasa yang ketika dimanfaatkan memiliki nilai tambah.

2) Kinerja Produk, adalah suatu nilai, fungsi atau hasil yang diperoleh dari suatu barang atau jasa. Konsumen akan membeli suatu barang atau jasa akan melihat nilai dan fungsi yang akan mereka dapatkan dari produk tersebut.

3) Tampilan Produk, merupakan kriteria fisik dari suatu produk seperti warna produk, porsi, bentuk, tekstur, aroma, rasa, dan tingkat kematangan.

\section{KEPUASAN KONSUMEN}

Tjiptono (2009) mengutip

dari Mowen bahwa kepuasan konsumen dirumuskan sebagai bentuk sikap atau perilaku konsumen terhadap suatu barang atau jasa yang telah dikonsumsi atau diperoleh, sehingga akan menimbulkan rencana untuk pembelian ulang serta menimbulkan rasa kepuasan atau ketidakpuasan.

Terdapat 5 indikator untuk Kepuasan konsumen, yaitu:

1) Kepuasan Pelanggan Keseluruhan, yaitu melalui kinerja produk secara umum

2) Dimensi Kepuasan Pelanggan, yaitu sebuah dimensi untuk mengukur kualitas pelayanan. Dengan menggunakan dimensi ini anda dapat mengetahui jarak antara ekspektasi pelanggan dengan harapan pelanggan terhadap layanan yang mereka terima. 
3) Konfirmasi Harapan, yaitu pengukuran kepuasan secara tidak langsung yang dilakukan dengan menyimpulkan kesesuaian atau ketidakpuasan antara harapan pelanggan dengan kinerja aktual suatu produk.

4) Niat Beli Ulang, yaitu kepuasan yang diukur berdasarkan kesediaan/kemauan pelanggan untuk melakukan pembelian kembali atas pelayanan sama yang telah dikonsumsi sebelumnya.

5) Kesediaan Untuk Merekomendasikan, yaitu kepuasan yang diukur ketika pelanggan melakukan marketing secara tidak langsung kepada seseorang atau sekelompok orang untuk melakukan pembelian terhadap produk yang ia gunakan/konsumsi.

\section{METODE PENELITIAN}

Penelitian ini menggunakan Metode Kuantitatif dengan metode pengukuran data kuantitatif dan statistika objektif melalui perhitungan ilmiah yang berasal dari sampel Konsumen KFC Lampung yang diminta menjawab sejumlah pertanyaan dalam kuesioner untuk menentukan frekuensi dan persentase tanggapan mereka.

Teknik analisis data yang digunakan dalam penelitian ini menggunakan analisis partial least square (PLS) dari data yang disajikan adalah seluruh informasi data yang sudah didapat.

PLS merupakan suatu teknik statistik multivariate yang bisa untuk menangani banyak variabel eksplanatori sekaligus diolah menggunakan aplikasi SmartPLS, dan data yang dihasilkan berupa tulisan, tabel, dan grafik agar memudahkan dalam menganalisis data untuk mendapatkan hasil yang sistemati.

\section{PEMBAHASAN}

\section{Isi Hasil dan Pembahasan}

Berdasarkan hasil uji yang dilakukan Terdapat 92 responden yang mengisi kuisoner mengenai Pengaruh Kualitas Pelayanan dan Kualitas Produk terhadap Kepuasan Konsumen pada Restoran KFC Lampung.

Diantaranya perempuan berjumlah 69 orang dan laki-laki berjumlah orang 23, dengan usia 17 sampai 26 tahun dengan rata-rata pekerjaan seorang mahasiswa, pelajar dan wiraswasta.

Outer loadings adalah tabel yang berisi loading factor untuk menunjukkan besar korelasi antara indikator dengan variabel laten. Nilai loading factor harus > 0,7 maka dikatakan valid. Output outer loadings dapat diperoleh dari PLS Algorithm Report SmartPLS.

\section{Hasil Uji Validitas dan Reliabilitas}

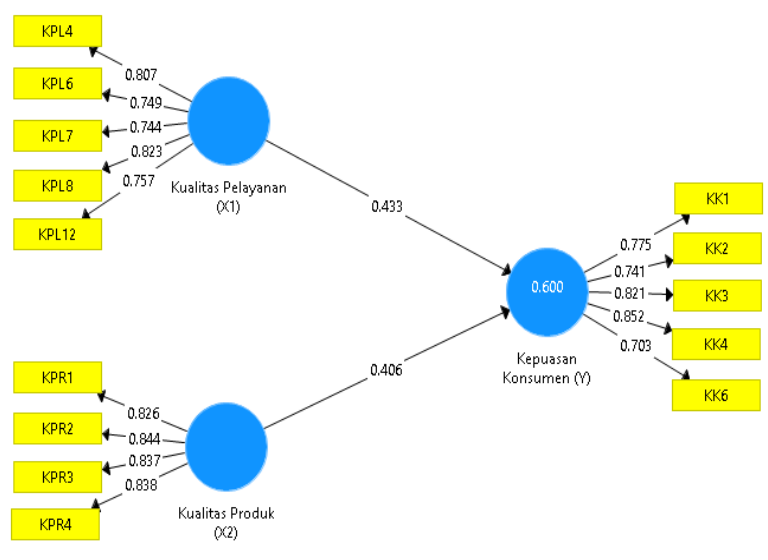

Keterangan :

KPL : Kualitas Pelayanan

KPR : Kualitas produk

KK : Lingkungan Kerja 


\section{Hasil Uji Validitas dan reabilitas}

Sebelum Uji T-Statistik terlebih dahulu dilakukan Uji Validitas dan Reliabilitas terhadap data yang akan diteliti, untuk menghindari data-data yang tidak valid yang dapat mengakibatkan terjadinya ketidakoptimalan dalam penelitian.

Berdasarkan dari hasil Validitas dan Reliabilitas yang dilakukan terdapat beberapa item kuesioner yang gugur karena tidak memenuhi batas standar nilai loading factor sehingga perlu di eliminasi ulang. Pada Variabel Kualitas Pelayanan (X1) terdapat 7 item yang gugur dari 12 item. Kemudian pada Variabel Kualitas Produk (X2) terdapat 2 item yang gugur dari 6 item sedangkan pada Variabel Kepuasan Konsumen (Y) terdapat 2 item yang gugur dari I item. Selanjutnya dilakukan pengujian ulang terhadap validitas sehingga didapat Semua indikator memiliki hubungan positif terhadap masing-masing variabel laten dan semua nilai item indikator berada diatas standar nilai loading factor di atas $>0.7$.

Hasil tersebut menunjukan bahwa penggunaan masing-masing indikator tersebut dinyatakan mampu mengukur variabel laten secara tepat.

\section{Hasil Uji Validitas}

\begin{tabular}{|c|c|c|c|}
\hline Item & $\begin{array}{c}\text { Kualitas } \\
\text { Pelayanan }\end{array}$ & $\begin{array}{c}\text { Kualitas } \\
\text { Produk }\end{array}$ & $\begin{array}{c}\text { Kepuasan } \\
\text { Konsumen }\end{array}$ \\
\hline KPL4 & 0.807 & & \\
\hline KPL6 & 0.749 & & \\
\hline KPL7 & 0.744 & & \\
\hline KPL8 & 0.823 & & \\
\hline KPL12 & 0.757 & & \\
\hline KPR1 & & 0.826 & \\
\hline KPR2 & & 0.844 & \\
\hline KPR3 & & 0.837 & 0.775 \\
\hline KPR4 & & 0.838 & 0.741 \\
\hline KK1 & & & 0.821 \\
\hline KK2 & & & 0.852 \\
\hline KK3 & & & 0.703 \\
\hline KK4 & & & \\
\hline KK6 & & & \\
\hline
\end{tabular}

\section{Hasil Uji Reliabilitas}

\begin{tabular}{|c|c|c|c|c|}
\hline & $\begin{array}{c}\text { Cronbach's } \\
\text { Alpha }\end{array}$ & rho_A & $\begin{array}{c}\text { Composite } \\
\text { Reliability }\end{array}$ & AVE \\
\hline $\begin{array}{c}\text { Kualitas } \\
\text { Pelayanan (X1) }\end{array}$ & 0.836 & 0.849 & 0.884 & 0.603 \\
\hline $\begin{array}{c}\text { Kualitas Produk } \\
(X 2)\end{array}$ & 0.857 & 0.860 & 0.903 & 0.700 \\
\hline $\begin{array}{c}\text { Kepuasan } \\
\text { Konsumen (Y) }\end{array}$ & 0.839 & 0.849 & 0.886 & 0.608 \\
\hline
\end{tabular}

\section{Hasil Uji Hipotesis}

\begin{tabular}{|l|c|c|c|c|c|}
\hline & $\begin{array}{c}\text { Original } \\
\text { Sample }\end{array}$ & $\begin{array}{c}\text { Sample } \\
\text { Mean (M) }\end{array}$ & $\begin{array}{c}\text { Standard } \\
\text { Deviation } \\
\text { (STDEV) }\end{array}$ & $\begin{array}{c}\text { T Statistics } \\
(\text { (10/STDEV) })\end{array}$ & $\begin{array}{c}P \\
\text { Values }\end{array}$ \\
\hline $\begin{array}{l}\text { Kualitas } \\
\text { Pelayanan- } \\
>\text { Kepuasan } \\
\text { Konsumen }\end{array}$ & 0.433 & 0.431 & 0.095 & 4.555 & 0.000 \\
\hline $\begin{array}{l}\text { Kualitas } \\
\text { Produk } \rightarrow \\
\text { Kepuasan } \\
\text { Konsumen }\end{array}$ & 0.406 & 0.409 & 0.099 & 4.112 & 0.000 \\
\hline
\end{tabular}

Berdasarkan hasil analisis, dapat disimpulkan bahwa hasil dari pengujian 
hipotesis dalam penelitian ini adalah sebagai berikut :

Hipotesis 1 : Kualitas pelayanan berpengaruh positif signifikan terhadap kepuasan konsumen.

Pada tabel ini menguji apakah kualitas pelayanan berpengaruh secara positif terhadap kepuasan konsumen. Dari hasil pengujian data berdasarkan survey yang telah dilakukan melalui PLS didapatkan hasil bahwa kualitas pelayanan berpengaruh positif signifikan terhadap kepuasan konsumen dengan nilai Pvalue sebesar $(0.000<0.05)$. Artinya hipotesis satu ini sudah terbukti dan hipotesis $\mathbf{H}_{1}$ diterima.

Hipotesis 2 : Kualitas produk berpengaruh positif signifikan terhadap kepuasan konsumen.

Pada tabel ini menguji apakah kualitas produk berpengaruh secara positif terhadap kepuasan konsumen. Dari hasil pengujian data berdasarkan survey yang telah dilakukan melalui PLS didapatkan hasil bahwa kualitas produk berpengaruh positif signifikan terhadap kepuasaan konsumen dengan nilai $\mathrm{P}$-value sebesar $(0.000<0.05)$. Artinya hipotesuis kedua ini sudah terbukti dan hipotesis $\mathbf{H}_{2}$ diterima.

\section{KESIMPULAN}

Berdasarkan hasil pengujian yang telah dilakukan diatas, dapat disimpulkan bahwa pengaruh kualitas pelayanan berpengaruh signifikan positif terhadap kepuasan konsumen pada Restoran KFC Lampung. Semakin konsumen menganggap kualitas pelayanan berkualitas maka kepuasan konsumen akan semakin tinggi. Begitupula dengan pengaruh kualitas produk berpengaruh positif signifikan terhadap kepuasan konsumen pada Restoran KFC Lampung, dimana semakin baik kualitas suatu produk maka kepuasaan konsumen semakin tinggi. Dapat disimpulkan bahwa variabel yang dipilih oleh peneliti sangat berpengaruh pada kepuasan konsumen pada Restoran KFC Lampung.

\section{SARAN}

Disarankan kepada Restoran KFC Lampung untuk dapat lebih memberikan kualitas Pelayanan dan Kualitas Produk yang terbaik karena kedua hal ini memberikan pengaruh yang positif dan signifikan terhadap Kepuasan Konsumen KFC Lampung. Dikarenakan peneliti hanya terfokus pada satu objek penelitian yaitu Restoran KFC Lampung, maka disarankan untuk penelitian selanjutnya untuk menggunakan objek penelitian lainnya.

$$
\text { Peneliti selanjutnya dapat }
$$
memperbaiki keterbatasan yang ada dalam penilitian ini dengan cara pengambilan data lain yang lebih lengkap untuk mendapatkan hasil yang menyeluruh.Peneliti selanjutnya diharapkan dapat mengembangkan penelitian dengan meneliti menggunakan variabel-variabel lain yang ada diluar penelitian ini atau dengan mengkombinasikan variabel yang terdapat dalam penelitian ini dengan variabel lain. 


\section{DAFTAR PUSTAKA}

Assauri, Sofjan. 2015. Manajemen

Pemasaran. Jakarta : Rajawali Pers. Sangadji, E.M dan Sopiah 2015. Prilaku Konsumen : Pendekatan Praktis Disertai: Himpunan Jurnal Penelitian. Yogyakarta : Andi.

Familiar, K., \& Ida Maftukhah. (2015). Pengaruh Kualitas Produk dan Kualitas Pelayanan terhadap Loyalitas Pelanggan Melalui Kepuasan Pelanggan. Management Analysis Journal, 4(4), 348-354

Hartanto, A. (2019). Pengaruh Kualitas

Produk, Kualitas Layanan dan Lingkungan Fisik Terhadap Loyalitas Pelanggan Melalui Kepuasan Pelanggan Sebagai Variabel Mediasi di De Mandailing Cafe Surabaya. Agora, 7(1), 2019.

Joko Bagio Santoso. 2019. "Pengaruh Kualitas Produk, Kualitas Pelayanan, Dan Harga Terhadap Kepuasan Dan Loyalitas Konsumen (Studi Pada Konsumen Geprek Bensu Rawamangun)" 16 (01): 127-46.

Kastawan mandala, and Muhammad Ryan Fauzi. 2019. "Purposive Sampling." Pengaruh Kualitas Pelayanan Dan Inovasi Produk Terhadap Kepuasan Untuk Meningkatkan Loyalitas Pelanggan 8 (11): 6741-61.

Kolter,P.,\& Keller, K.L. (2009). Manajemen pemasaran (12th Ed;
PT Indeks, Ed.). Jakarta : PT Mancana Jaya Cemerlang

Krisdianti, Dika Lambang, and Fakultas Ilmu Administrasi. 2019. "Pengaruh Kualitas Pelayanan Terhadap Kepuasan Konsumen Pada Restoran Pizza Hut Malang Town Square" 70 (1): 36-44.

Malik Ibrahim Siti Marijam Thawil. 2019. "Pengaruh Kualitas Produk Terhadap Kepuasan Pelanggan" 4 (1): $175-82$.

Purnomo Edwin Setyo. 2017. "Pengaruh Kualitas Produk Dan Harga Terhadap Kepuasan Konsumen 'Best Autoworks"' 1.

Sugiyono. (2016). " Metode penelitian kuantitatif, kualitatif dan $R \& D "$. Bandung: Alfabeta

Tjiptono, Fandy. 2012. Service, Quality \& Satisfaction (Yogyakarta: CV Andi Offset)

Weenas, Jackson R.S. 2013. Kualitas Produk, Harga, Promosi, dan Kualitas Pelayanan Pengaruhnya Terhadap Keputusan Pembelian Spring Bed Comforta. Jurnal EMBA vol.1 no.4 Desember 2013 